\title{
Tropical parabiotic ants: Highly unusual cuticular substances and low interspecific discrimination Florian Menzel $^{1}$, Nico Blüthgen ${ }^{1}$ and Thomas Schmitt*2
}

Address: ${ }^{1}$ University of Würzburg, Biocenter, Department of Animal Ecology and Tropical Biology, Am Hubland, 97074 Würzburg, Germany and ${ }^{2}$ University of Freiburg, Institute of Biology I (Zoology), Department of Evolutionary Biology and Animal Ecology, Hauptstr.1, 79104 Freiburg, Germany

Email: Florian Menzel - menzel@biozentrum.uni-wuerzburg.de; Nico Blüthgen - bluethgen@biozentrum.uni-wuerzburg.de; Thomas Schmitt* - thomas.schmitt@biologie.uni-freiburg.de

* Corresponding author

Published: 20 October 2008

Frontiers in Zoology 2008, 5:16 doi:10.1186/1742-9994-5-16
Received: 30 May 2008

Accepted: 20 October 2008

This article is available from: http://www.frontiersinzoology.com/content/5/I/16

(c) 2008 Menzel et al; licensee BioMed Central Ltd.

This is an Open Access article distributed under the terms of the Creative Commons Attribution License (http://creativecommons.org/licenses/by/2.0), which permits unrestricted use, distribution, and reproduction in any medium, provided the original work is properly cited.

\begin{abstract}
Background: Associations between animal species require that at least one of the species recognizes its partner. Parabioses are associations of two ant species which co-inhabit the same nest. Ants usually possess an elaborate nestmate recognition system, which is based on cuticular hydrocarbons and allows them to distinguish nestmates from non-nestmates through quantitative or qualitative differences in the hydrocarbon composition. Hence, living in a parabiotic association probably necessitates changes of the nestmate recognition system in both species, since heterospecific ants have to be accepted as nestmates.

Results: In the present study we report highly unusual cuticular profiles in the parabiotic species Crematogaster modiglianii and Camponotus rufifemur from the tropical rainforest of Borneo. The cuticle of both species is covered by a set of steroids, which are highly unusual surface compounds. They also occur in the Dufour gland of Crematogaster modiglianii in high quantities. The composition of these steroids differed between colonies but was highly similar among the two species of a parabiotic nest. In contrast, hydrocarbon composition of $\mathrm{Cr}$. modiglianii and $\mathrm{Ca}$. rufifemur differed strongly and only overlapped in three regularly occurring and three trace compounds. The hydrocarbon profile of Camponotus rufifemur consisted almost exclusively of methyl-branched alkenes of unusually high chain lengths (up to $\mathrm{C}_{49}$ ). This species occurred in two sympatric, chemically distinct varieties with almost no hydrocarbons in common. Cr. modiglianii discriminated between these two varieties. It only tolerated workers of the $\mathrm{Ca}$. rufifemur variety it was associated with, but attacked the respective others. However, Cr. modiglianii did not distinguish its own Ca. rufifemur partner from allocolonial $C a$. rufifemur workers of the same variety.

Conclusion: We conclude that there is a mutual substance transfer between $\mathrm{Cr}$. modiglianii and $\mathrm{Ca}$. rufifemur. Ca. rufifemur actively or passively acquires cuticular steroids from its $\mathrm{Cr}$. modiglianii partner, while the latter acquires at least two cuticular hydrocarbons from $\mathrm{Ca}$. rufifemur. The cuticular substances of both species are highly unusual regarding both substance classes and chain lengths, which may cause the apparent inability of $\mathrm{Cr}$. modiglianii to discriminate $\mathrm{Ca}$. rufifemur nestmates from allocolonial $\mathrm{Ca}$. rufifemur workers of the same chemical variety.
\end{abstract}




\section{Background}

Associations across different animal taxa require specific adaptations on one or both sides. In particular, recognizing the partner species is a crucial task to any form of association, albeit in host-parasite associations only the latter might need to recognize the partner [1]. Nestmate recognition mechanisms in associating species must therefore go beyond the own species and include the partner species.

In ants, one of the closest and most intriguing interspecific associations is parabioses, where two ant species live together in a common nest. This phenomenon is found in several parts of the world, including Southeast Asia [2] and tropical South America [3]. Parabiotic ants have nestmates not only from their own colony, but also from a completely different species. Their nestmate recognition system therefore needs to include allospecific nestmates. In ants and other social hymenoptera, recognition is based on colony-specific chemical cues on the body surface that are perceived through olfactory or contact chemoreception [4,5]. Most of them are hydrocarbons [6-8]. Via allogrooming and trophallaxis, the individuals continually take up their nestmates' surface compounds into the postpharyngeal gland (PPG), where they are mixed and redistributed. Through this process, a colony-specific odour is created [5,9-11]. This colony-specific odour is learned by the colony members and represented as a neuronal template in the nervous system [12]. Nestmates are recognized by comparing the cuticular profile of the encountered individual to the neuronal template (phenotype matching), whereby a mismatch generally results in aggression [5].

Despite this complex nestmate recognition system, a considerable number of insect species manages to be accepted in Hymenoptera colonies, such as Lycaenid larvae, Staphylinidae, Ensifera, and Diptera [13-16] as well as social parasites, such as the parasitic bumblebee Psithyrus [17] and inquiline ant species $[1,6]$. In many of these associations, the parasite chemically resembles the host (chemical mimicry) [1,13-16,18,19]. Another possible mechanism to remain incognito is chemical insignificance [1]. Several social parasite species are - like callows - chemically insignificant, i.e. they do not possess an individual surface profile and are hence not recognized as foreign by their hosts $[1,20,21]$. Hydrocarbon profiles of very long chain lengths are difficult to perceive and hence may also promote chemical insignificance [22,23]. Still, numerous other social parasite species possess distinct profiles that do not resemble their hosts. Since these profiles neither show chemical mimicry nor insignificance, it has been supposed that the host species habituate to the parasites' profiles [24-26].
While the chemical mechanisms of tolerance between species have been studied in associations like social parasitism, little is known about parabiotic associations. It seems likely that parabiotic ants possess a nestmate recognition system that tolerates allospecific nestmates. In the present study we examined the relationship between interspecific tolerance and surface chemistry among the Southeast Asian parabiotic species Crematogaster modiglianii and Camponotus rufifemur. The two species tolerate ants from certain (but not all) foreign parabiotic nests but attack non-parabiotic ant species [2]. We discovered that two morphological varieties of Ca. rufifemur (the 'red' and the 'black' variety, see Methods) also differ in their chemical profiles. This enabled us to study two different levels of chemical similarity - within and between the two varieties. Our research questions were:

(1) Do parabiotic species possess cuticular substances different from related, non-parabiotic species?

(2) Is there evidence for chemical mimicry, i.e., chemical overlap between parabiotic partners?

(3) Do chemical differences within species account for differences in interspecific allocolonial tolerance?

\section{Results \\ Cuticular substances: Hydrocarbons and other aliphatic components}

The cuticular profile of both Camponotus rufifemur and Crematogaster modiglianii highly differed from other, nonparabiotic Camponotus and Crematogaster species [9,2729]; unpublished data]. While there were only few aliphatic compounds with a chain length of C20-C33, both species possessed hydrocarbons of very high chain lengths (C35 up to C49, Figure 1) as well as steroids, which have not previously been detected on insect cuticles. The aliphatic profile of Crematogaster modiglianii consisted of hydrocarbons between C33 and C40. Beside nalkanes and methyl-branched alkanes, more than $68 \%$ of its aliphatic cuticular compounds were unsaturated (Figure $1 \mathrm{a}$, Tables 1, 2). Extracts of the body surface and postpharyngeal glands contained the same aliphatic substances in similar quantitative composition.

The Camponotus rufifemur surface profile mainly contained compounds beyond $\mathrm{C}_{38}$, beside traces of lighter components. The two morphological varieties exhibit almost completely different surface profiles. The only substances in common were trace n-alkanes between C27 and C30 and C37-9-ene (Table 1). The red variety exhibited a highly unusual cuticular profile, $98 \%$ of the hydrocarbon quantities being methyl-branched alkenes. The main compounds, 27-MeC39-14-ene and 27-MeC39-16-ene, accounted for $88.7 \%$ of the total hydrocarbons. The other 

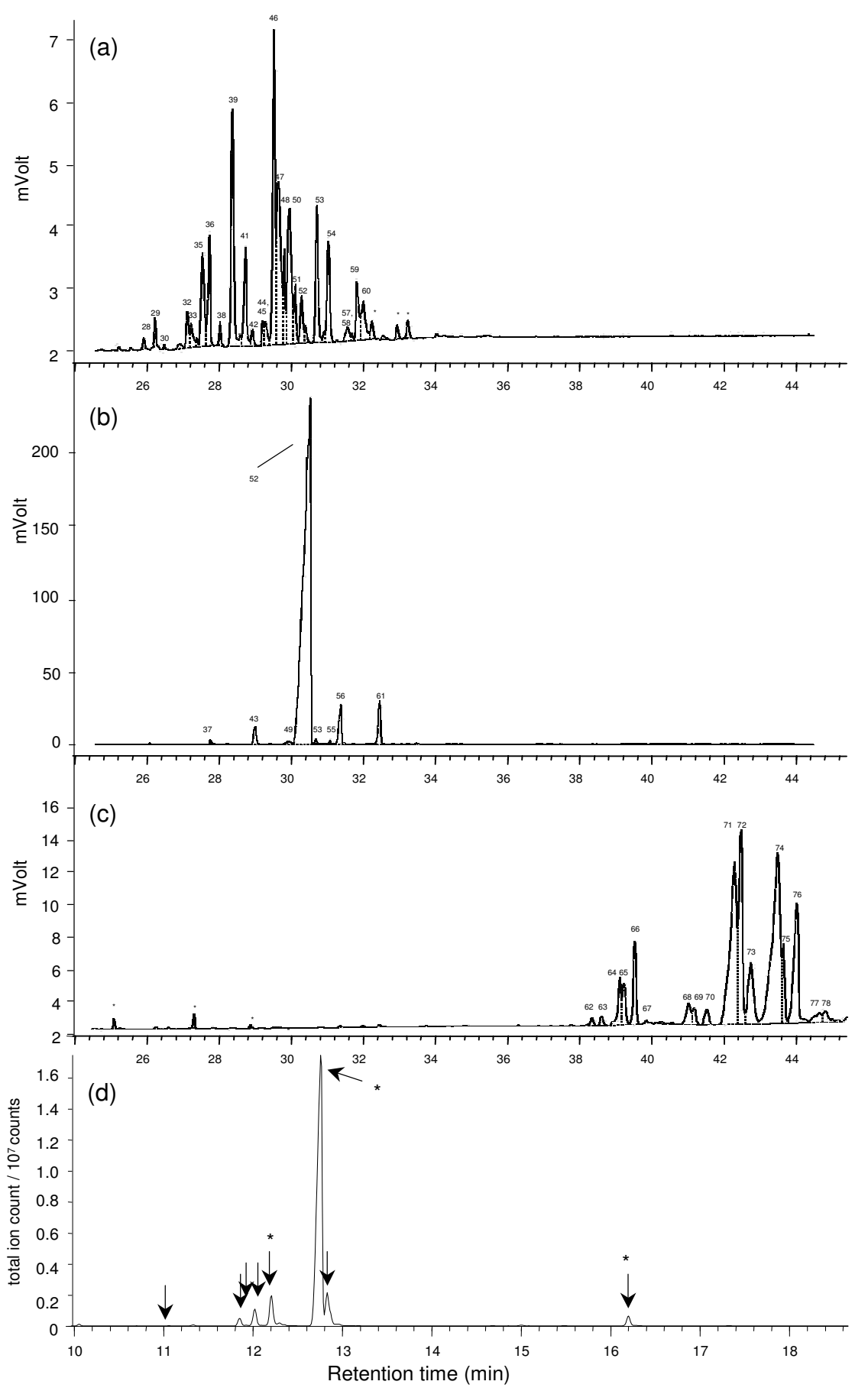

Figure I

Gas chromatograms of cuticular hydrocarbons of the parabiotic ant species. (a) Crematogaster modiglianii B2, (b) red Camponotus rufifemur R2, (c) black Camponotus rufifemur B4. Graphs were acquired with a GC-FID. Only substances beyond a chain length of 34 are shown since shorter hydrocarbons make up less than $2 \%$ of the profile. Numbers refer to table I.

*unknown, irregularly occurring substance. (d) Typical chromatogram of the cuticular steroids of $\mathrm{Cr}$. modiglianii, acquired with GC-MS. Arrows indicate the steroid compounds common to both $\mathrm{Cr}$. modiglianii and $\mathrm{Ca}$. rufifemur. Asterisks indicate the three steroids with highly similar mass spectra used for the second Mantel test. No other steroids were present in the colony shown. 
Table I: Aliphatic cuticular substances found in Crematogaster modiglianii and the two varieties of Camponotus rufifemur

\begin{tabular}{|c|c|c|c|c|c|c|}
\hline & substance & substance class & retention index & red Ca. rufifemur & black Ca. rufifemur & Cr. modiglianii \\
\hline 1 & C2I & n-alkane & 21 & & $0.26 \pm 0.01 \%$ & \\
\hline 2 & C23:I & n-alkene & 22.75 & & $0.46 \pm 0.03 \%$ & \\
\hline 3 & unknown & unknown & 22.9 & & $0.20 \pm 0.01 \%$ & \\
\hline 4 & $\mathrm{C} 23$ & n-alkane & 23 & & $0.16 \pm 0.01 \%$ & \\
\hline 5 & C24:I & n-alkene & 23.78 & & $0.49 \pm 0.06 \%$ & \\
\hline 6 & Docosenal $^{+}$ & aldehyde & 24.07 & & $0.40 \pm 0.09 \%$ & \\
\hline 7 & Docosenal $^{+}$ & aldehyde & 24.12 & & $0.20 \pm 0.16 \%$ & \\
\hline 8 & unknown & unknown & 24.35 & & $0.23 \pm 0.06 \%$ & \\
\hline 9 & I2-MeC24 & branched alkane & 24.37 & $0.06 \pm 0.05 \%$ & & \\
\hline 10 & II-MeC24 & branched alkane & 24.39 & & $0.45 \pm 0.02 \%$ & \\
\hline II & $\mathrm{C} 25$ & n-alkane & 25 & & & \\
\hline 12 & Tricosenal $^{+}$ & aldehyde & 25.11 & & $0.11 \pm 0.09 \%$ & \\
\hline 13 & unknown & unknown & 25.69 & $0.05 \pm 0.02 \%$ & & \\
\hline 14 & unknown & unknown & 25.7 & & $0.67 \pm 0.17 \%$ & \\
\hline 15 & C26 & n-alkane & 26 & $0.02 \pm 0.01 \%$ & & \\
\hline 16 & Tetracosenal $^{+}$ & aldehyde & 26.09 & & $0.72 \pm 0.17 \%$ & \\
\hline 17 & unknown & unknown & 26.37 & & $0.21 \pm 0.03 \%$ & \\
\hline 18 & unknown & unknown & 26.72 & & $0.08 \pm 0.02 \%$ & \\
\hline 19 & $\mathrm{C} 27$ & n-alkane & 27 & $0.13 \pm 0.11 \%$ & $0.13 \pm 0.01 \%$ & \\
\hline 20 & Pentacosenal $^{+}$ & aldehyde & 27.15 & & $0.47 \pm 0.39 \%$ & \\
\hline 21 & unknown & unknown & 27.71 & $0.09 \pm 0.04 \%$ & & \\
\hline 22 & unknown & unknown & 27.73 & & $0.52 \pm 0.08 \%$ & \\
\hline 23 & $\mathrm{C} 28$ & n-alkane & 28 & $0.09 \pm 0.06 \%$ & $0.14 \pm 0.01 \%$ & \\
\hline 24 & $\mathrm{C} 29$ & n-alkane & 29 & $0.21 \pm 0.17 \%$ & $0.27 \pm 0.02 \%$ & \\
\hline 25 & $\mathrm{C} 30$ & n-alkane & 30 & $0.01 \pm 0.01 \%$ & $0.20 \pm 0.03 \%$ & \\
\hline 26 & C3I & n-alkane & 31 & $0.15 \pm 0.11 \%$ & & \\
\hline 27 & C32 & n-alkane & 32 & & $0.08 \pm 0.03 \%$ & \\
\hline 28 & C35:I & n-alkene & 34.85 & & $0.26 \pm 0.09 \%$ & $0.15 \pm 0.04 \%$ \\
\hline 29 & C35 & n-alkane & 35.05 & & $0.15 \pm 0.06 \% *$ & $0.76 \pm 0.11 \%$ \\
\hline 30 & $\begin{array}{l}\text { 17-MeC35, 15-MeC35, } 13- \\
\text { МeC35 }\end{array}$ & branched alkane & 35.31 & & & $0.88 \pm 0.25 \%$ \\
\hline 31 & $3-\mathrm{MeC} 35$ & branched alkane & 35.74 & & & $0.3 \pm 0.13 \%$ \\
\hline 32 & C37:2 & n-alkadiene & 36.42 & & & $2.31 \pm 0.28 \%$ \\
\hline 33 & C37:2 & n-alkadiene & 36.51 & & & $1.56 \pm 0.12 \%$ \\
\hline 34 & $\mathrm{C} 37: 2$ & n-alkadiene & 36.64 & & & $0.45 \pm 0.07 \%$ \\
\hline 35 & $\begin{array}{l}\text { C37-I3-ene, C37-I4-ene, C37- } \\
\text { I5-ene, C37-16-ene }\end{array}$ & n-alkene & 36.72 & & & $5.43 \pm 0.49 \%$ \\
\hline 36 & C37-9-ene & n-alkene & 36.86 & & $0.48 \pm 0.15 \%$ & $4.53 \pm 0.4 \%$ \\
\hline 37 & $\begin{array}{l}\text { 25-MeC37-14-ene, 25-MeC37- } \\
\text { 16-ene }{ }^{++}\end{array}$ & branched alkene & 36.96 & $0.44 \pm 0.07 \%$ & & \\
\hline 38 & C37 & n-alkane & 37.05 & & & $0.52 \pm 0.1 \%$ \\
\hline 39 & $\begin{array}{l}\text { 19-МeС37, I7-МeС37, I5- } \\
\text { МeС37, І3-МeС37, II-МeС37 }\end{array}$ & branched alkane & 37.31 & & & $11.47 \pm 0.28 \%$ \\
\hline 40 & $\mathrm{C} 38: 2$ & n-alkadiene & 37.45 & & & $0.18 \pm 0.09 \%$ \\
\hline 41 & $\begin{array}{l}\text { II,27-DiMeC37, II,25- } \\
\text { DiMeC37 }\end{array}$ & branched alkane & 37.58 & & & $6.02 \pm 0.33 \%$ \\
\hline 42 & unknown & unknown & 37.79 & & & $0.63 \pm 0.1 \%$ \\
\hline 43 & $\begin{array}{l}x(25,26,27)-M e C 38- \\
y(13,14,15,16)-e^{++\S}\end{array}$ & branched alkene & 37.93 & $1.99 \pm 0.11 \%$ & & \\
\hline 44 & $\mathrm{C} 39: 3$ & n-alkatriene & 38.23 & & & $1.12 \pm 0.13 \%$ \\
\hline 45 & C39:3 & n-alkatriene & 38.3 & & & $1.46 \pm 0.19 \%$ \\
\hline 46 & C39:2 & n-alkadiene & 38.43 & & & $15.23 \pm 0.76 \%$ \\
\hline 47 & C39:2 & n-alkadiene & 38.53 & & & $13.7 \pm 0.73 \%$ \\
\hline 48 & C39-ene & n-alkene & 38.73 & & & $3.66 \pm 0.34 \%$ \\
\hline 49 & unknown & unknown & 38.79 & $0.55 \pm 0.08 \%$ & & \\
\hline 50 & C39:I & n-alkene & 38.79 & & & $7.62 \pm 0.19 \%$ \\
\hline 51 & C39:1 & n-alkene & 38.88 & & & $1.7 \pm 0.08 \%$ \\
\hline 52 & $\begin{array}{l}\text { 27-MeC39-14-ene, 27-MeC39- } \\
\text { 16-ene }\end{array}$ & branched alkene & 39.02 & $88.66 \pm 0.53 \%$ & & $3.15 \pm 1.18 \%$ \\
\hline 53 & $\begin{array}{l}\text { 19-МeС39, I7-МeС39, I5- } \\
\text { МeС39, 13-МeС39, II-МeС39 }\end{array}$ & branched alkane & 39.29 & $\begin{array}{c}0.52 \pm 0.24 \% \\
\text { (only 13-MeC39) }\end{array}$ & & $4.51 \pm 0.2 \%$ \\
\hline
\end{tabular}


Table I: Aliphatic cuticular substances found in Crematogaster modiglianii and the two varieties of Camponotus rufifemur (Continued)

\begin{tabular}{|c|c|c|c|c|c|c|}
\hline 54 & $\begin{array}{l}\text { II,2I-DiMeC39, II,23- } \\
\text { DiMeC39, II,27-DiMeC39, } \\
\text { II,29-DimeC39 }\end{array}$ & branched alkane & 39.54 & & & $4.84 \pm 0.52 \%$ \\
\hline 55 & unknown & unknown & 39.76 & $0.22 \pm 0.01 \%$ & & \\
\hline 56 & $\begin{array}{l}\text { 27-MeC40-I4-ene, 27-MeC40- } \\
\text { I5-ene, 27-MeC40-I6-ene }+ \text {-+ }\end{array}$ & branched alkene & 39.97 & $3.41 \pm 0.09 \%$ & & \\
\hline 57 & unknown & unknown & 40.17 & & & $1.04 \pm 0.18 \%$ \\
\hline 58 & C40:3 & n-alkatriene & 40.35 & & & $0.36 \pm 0.08 \%$ \\
\hline 59 & C40:2 & n-alkadiene & 40.42 & & & $3.39 \pm 0.24 \%$ \\
\hline 60 & C40:2 & n-alkadiene & 40.57 & & & $3.01 \pm 0.29 \%$ \\
\hline 61 & $\begin{array}{l}x(27,29)-M e C 4 I-y(14,16,18)- \\
e n e^{++\S}\end{array}$ & branched alkene & 40.94 & $3.35 \pm 0.4 \%$ & & \\
\hline 62 & unknown & unknown & 44.54 & & $0.65 \pm 0.12 \%$ & \\
\hline 63 & unknown & unknown & 44.68 & & $0.45 \pm 0.03 \%$ & \\
\hline 64 & unknown & unknown & 44.96 & & $3.34 \pm 0.19 \%$ & \\
\hline 65 & C45:I & n-alkene & 45.05 & & $3.01 \pm 0.04 \%$ & \\
\hline 66 & 36-MeC45:I & branched alkene & 45.18 & & $4.17 \pm 0.06 \%$ & \\
\hline 67 & unknown & unknown & 45.49 & & $1.09 \pm 0.4 \%$ & \\
\hline 68 & unknown & unknown & 45.89 & & $2.10 \pm 0.16 \%$ & \\
\hline 69 & unknown & unknown & 45.97 & & $0.98 \pm 0.06 \%$ & \\
\hline 70 & unknown & unknown & 46.11 & & $1.07 \pm 0.06 \%$ & \\
\hline 71 & C47:2 & n-alkadiene & 46.41 & & $|5.1| \pm 0.52 \%$ & \\
\hline 72 & C47:2 & n-alkadiene & 46.67 & & $8.72 \pm 0.37 \%$ & \\
\hline 73 & C47:I & n-alkene & 46.74 & & $4.43 \pm 0.18 \%$ & \\
\hline 74 & C48:I & n-alkene & 46.88 & & $22.95 \pm 0.96 \%$ & \\
\hline 75 & C48:I & n-alkene & 47.10 & & $4.10 \pm 0.07 \%$ & \\
\hline 76 & 38-MeC47:I & branched alkene & 47.16 & & $9.20 \pm 0.49 \%$ & \\
\hline 77 & unknown & unknown & 47.42 & & $1.49 \pm 0.12 \%$ & \\
\hline 78 & unknown & unknown & 47.46 & & $1.29 \pm 0.11 \%$ & \\
\hline 79 & unknown & unknown & 47.81 & & $1.91 \pm 0.13 \%$ & \\
\hline 80 & unknown & unknown & 48.01 & & $0.54 \pm 0.07 \%$ & \\
\hline 81 & C49:2 & n-alkadiene & 48.35 & & $2.55 \pm 1.7 \%$ & \\
\hline 82 & C49:2 & n-alkadiene & 48.45 & & $2.40 \pm 1.6 \%$ & \\
\hline 83 & C49:I & n-alkene & 48.59 & & $1.25 \pm 0.11 \%$ & \\
\hline
\end{tabular}

Relative peak areas (mean and standard error) for Ca. rufifemur and Cr. modiglianii are given based on FID data from n $=6$ (red Ca. rufifemur), 3 (black Ca. rufifemur), and 8 (Cr. modiglianii) colonies. ${ }^{*}$ found in less than $50 \%$ of the samples, ${ }^{+}$tentatively identified, ${ }^{++}$position of double bond tentative, $\S$ number of substances and their exact structure could not be further determined. Retention indices beyond 44 are extrapolated.

different methyl-branched alkenes were similar in respect to the positions of the methyl group and the double bond (Table 3). Chain lengths ranged from C38 to C41, with trace compounds between C24 and C37 (Figure 1b, Tables 1,2).

The profile of the black Ca. rufifemur variety consisted of even larger molecules, with $92.8 \%$ of the surface com- pounds between C44 and C49 (Table 1). At least 80\% of the compounds were unsaturated (Table 2). Methylbranched alkenes were also present, albeit not as abundant as in the red Ca. rufifemur variety. Minor compounds included n-alkanes, methyl-branched alkanes and aldehydes (Table 2). In both Ca. rufifemur varieties, PPG and surface extracts contained the same aliphatic compounds in similar relative quantities.

Table 2: Relative quantities of the different aliphatic substance classes in Cr. modiglianii and Ca. rufifemur.

\begin{tabular}{|c|c|c|c|}
\hline substance class & red $\mathrm{Ca}$. rufifemur & black Ca. rufifemur & Cr. modiglianii \\
\hline n-alkane & $0.64 \pm 0.41 \%$ & $1.25 \pm 0.18 \%$ & $1.29 \pm 0.16 \%$ \\
\hline n-alkene & $0 \pm 0 \%$ & $37.44 \pm 0.94 \%$ & $23.06 \pm 1.03 \%$ \\
\hline n-alkadiene & $0 \pm 0 \%$ & $28.77 \pm 2.41 \%$ & $39.83 \pm 1.09 \%$ \\
\hline n-alkatriene & $0 \pm 0 \%$ & $0 \pm 0 \%$ & $2.8 \pm 0.16 \%$ \\
\hline branched alkane & $0.58 \pm 0.26 \%$ & $0.45 \pm 0.02 \%$ & $28.07 \pm 0.85 \%$ \\
\hline branched alkene & $98.1 \pm 0.35 \%$ & $13.37 \pm 0.44 \%$ & $3.15 \pm 1.18 \%$ \\
\hline aldehyde & $0 \pm 0 \%$ & $1.9 \pm 0.78 \%$ & $0 \pm 0 \%$ \\
\hline unknown & $0.91 \pm 0.11 \%$ & $16.82 \pm 0.42 \%$ & $\mathrm{I} .77 \pm 0.28 \%$ \\
\hline
\end{tabular}

Mean and standard error are given, based on FID data from n = 6 (red Ca. rufifemur), 3 (black Ca. rufifemur), and 8 (Cr. modiglianii) colonies. 
Table 3: Diagnostic ions of the methyl-branched alkenes in the red Ca. rufifemur variety.

\begin{tabular}{|c|c|c|c|c|}
\hline substance No. & Substance & $\begin{array}{l}\text { diagnostic ions from } \\
\text { hydration }\end{array}$ & $\begin{array}{l}\text { diagnostic ions from DMDS } \\
\text { derivatization }\end{array}$ & $\begin{array}{l}\text { inferred double bond } \\
\text { position }\end{array}$ \\
\hline 37 & 25-MeC37-ene & 196,365 & $243^{*}, 271,355,383^{*}$ & $14^{*}, 16$ or $21,23^{*}$ \\
\hline 43 & $\begin{array}{l}\text { 25-MeC38-ene, 26-MeC37-ene, } \\
\text { 27-MeC38-ene }\end{array}$ & $182,196,210,364,379,393$ & $\begin{array}{l}229,243,257,27 I, 369,383 \\
397,411\end{array}$ & $\begin{array}{l}13,14,15,16 \text { or } 22,23,24 \text {, } \\
25\end{array}$ \\
\hline 52 & 27-Methyl-C39-ene & 196,393 & $243,27 I, 383,4 I I$ & $14^{* *}, 16^{* *}$ or 23,25 \\
\hline 56 & 27-Methyl-C40-ene & 210,393 & $243^{*}, 257,27 I, 397,4 I I, 425^{*}$ & $14^{*}, 15,16$ or $24,25,26^{*}$ \\
\hline 61 & 27-MeC4I-ene, 29-MeC4I-ene & $196,224,392,421$ & $243,27 I^{*}, 299,383,4 I I *, 439$ & $14,16^{*}, 18$ or $23,25^{*}, 27$ \\
\hline
\end{tabular}

*diagnostic ion/molecule with respective double bond position at least twice as abundant as remaining ions/molecules; ** position of double bond was confirmed at the positions 14 and 16 via cleavage after ozonisation

\section{Cuticular substances: Steroids}

Besides aliphatic compounds, the surface profile of both ant species contained up to 24 components with a basic steroid structure (as inferred from mass spectra and diagnostic ions). Their mass spectra indicate a close chemical interrelatedness of the compounds. Due to the high substance quantities necessary for NMR analysis, their spatial molecular structure has not yet been resolved but is under investigation. Crematogaster modiglianii possessed high amounts of steroids on the body surface $(2.59 \pm 0.58 \mu \mathrm{g} /$ worker, $\mathrm{n}=11$ colonies, mean and SE) which by far exceeded the hydrocarbons $(0.48 \pm 0.05 \mu \mathrm{g} /$ worker, $\mathrm{n}=11$ colonies, mean and SE). In contrast, postpharyngeal gland extracts only contained minor amounts of steroids but high quantities of hydrocarbons. High steroid amounts of the same quantitative composition were also found in the Dufour gland, in separate alitrunk and gaster cuticular extracts and, albeit in lower amounts, in head cuticular extracts. They also occurred in cuticular extractions of living ants with SPME fibres, thus confirming that their presence in hexane extracts was not an artefact of concomitantly extracted glands. Altogether, Cr. modiglianii extracts contained 24 different steroid components with an abundance higher than $0.1 \%$ in at least one colony (percent of total steroid abundance). Their retention indices ranged between 20.38 and 25.77. Six of the 24 steroids were found in all Cr. modiglianii colonies in similar relative compositions. An additional eleven steroids were abundant in certain colonies but absent in others. The remaining seven steroids were irregularly found and never occurred in relative abundances higher than $1 \%$ (percent of total steroid abundance). Camponotus rufifemur extracts (both varieties) contained up to eight different steroids, all of which also occurred in $\mathrm{Cr}$. modiglianii. The absolute steroid quantities in Ca. rufifemur were lower than the hydrocarbon quantities (black variety: $0.66 \pm$ $0.22 \mu \mathrm{g}$ steroids/worker and $1.79 \pm 0.29 \mu \mathrm{g}$ hydrocarbons/ worker, $\mathrm{n}=3$ colonies; red variety: $0.41 \pm 0.14 \mu \mathrm{g}$ steroids/ worker and $9.71 \pm 3.79 \mu \mathrm{g}$ hydrocarbons/worker, $\mathrm{n}=4$ colonies, mean and SE given).

\section{Chemical overlap among the parabiotic species}

Six hydrocarbons were shared between both parabiotic species. The red $\mathrm{Ca}$. rufifemur variety shared three hydrocarbons with Cr. modiglianii. These were the two methylbranched alkenes, 27-MeC39-14-ene and 27-MeC39-16ene, which are the main constituents of the red Ca. rufifemur surface profile, and its saturated derivative, 13MeC39 (Table 1). All three are absent in the black $\mathrm{Ca}$. rufifemur variety. Cr. modiglianii colonies living with the red $\mathrm{Ca}$. rufifemur variety (henceforth, 'red' $\mathrm{Cr}$. modiglianii) exhibited significantly more 27-MeC39-14-ene and 27MeC39-16-ene than those associated with the black variety (henceforth, 'black' Cr. modiglianii) (Mann-Whitney W $=30, \mathrm{p}=0.0043 ; \mathrm{N}_{1}=5, \mathrm{~N}_{2}=6$ colonies, Figure 2). The quantities of 13-MeC39 were not compared since they could not be separated from other methyl-branched C39 alkanes in Cr. modiglianii (Table 1). Traces of three other hydrocarbons common in Cr. modiglianii were detected in the black Ca. rufifemur variety (C35:1, C35, C37-9-ene, Table 1). Albeit the associated Cr. modiglianii possessed slightly more C37-9-ene than those living with the red variety, no significant differences were found.

Eight of the steroids common in $\mathrm{Cr}$. modiglianii were also frequently found in $\mathrm{Ca}$. rufifemur (inclusion criterion: median abundance $>0 \%$ in 11 colonies of both species; Figure 1d). Their relative abundances varied between parabiotic nests but were significantly correlated among the two species within a nest (Mantel test: $\mathrm{r}=0.49, \mathrm{p}=$ $0.041, \mathrm{~N}=11$; Bray-Curtis distances: $0.13 \pm 0.08$ (Ca. rufifemur), $0.43 \pm 0.31$ (Cr. modiglianii); mean and s.d.). A second Mantel test considered only three steroids with very similar mass spectra, which were present in all extracts (retention indices: 21.92, 22.24, 24.47; marked with asterisks in Figure 1d). This test yielded a highly significant correlation of steroid abundance among the two species of each parabiotic nest $(\mathrm{r}=0.620, \mathrm{p}<0.001, \mathrm{~N}=11$; Bray-Curtis distances: $0.06 \pm 0.04$ (Ca. rufifemur), $0.13 \pm$ 0.07 (Cr. modiglianii)). 


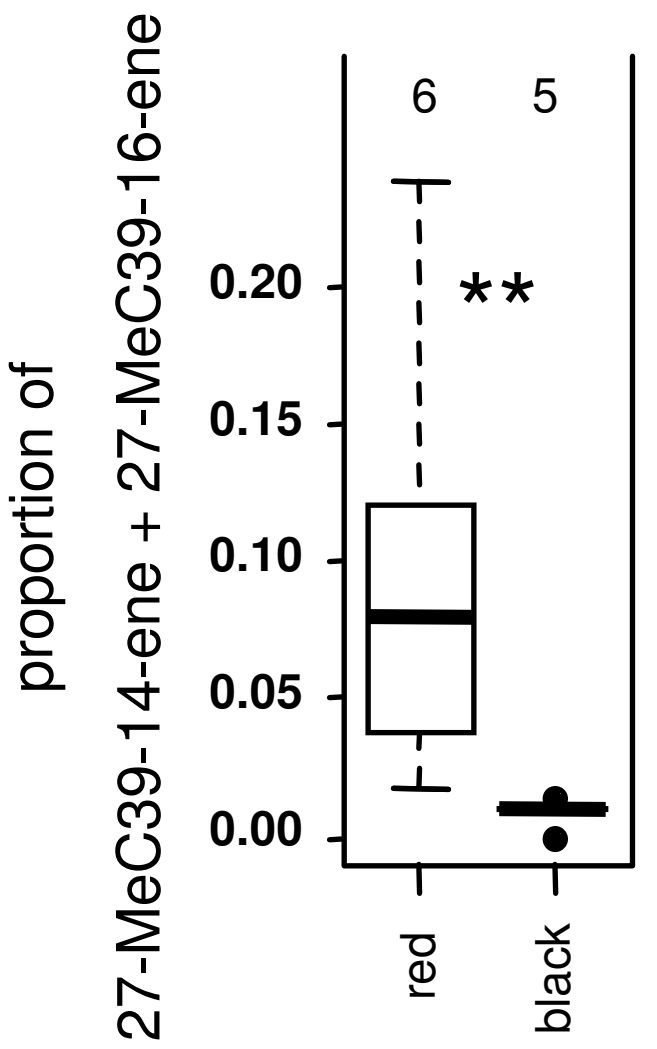

Figure 2

Relative abundance of 27-MeC39-I4-ene and 27MeC39-I6-ene in Cr. modiglianii workers living with the red vs. Cr. modiglianii workers living with the black Ca. rufifemur variety. Median, quartiles, range, and outliers (i.e. all data points deviating from the box by more than I.5 times the interquartile range) are shown in the present and the following figures. The number of analyzed colonies is given above each plot. $* *$ highly significant $(\mathrm{p}=$ 0.0043 ) according to $U$ test.

\section{Differences in allocolonial tolerance}

Chemical differences between the two $\mathrm{Ca}$. rufifemur varieties accounted for much of the variance in interspecific confrontations. In general, $\mathrm{Cr}$. modiglianii workers tolerated only allocolonial $\mathrm{Ca}$. rufifemur workers of the variety they were associated with. The focal Crematogaster modiglianii colony, which lived together with the red $\mathrm{Ca}$. rufifemur variety, showed high aggression towards dead workers of the black Ca. rufifemur variety but not towards those of the red one (Figure 3). The generalized linear model (GLM) for total aggression explained $65.6 \%$ of the total deviance and yielded a highly significant effect of the Camponotus variety (58.7\% explained deviance, Table 4). The remaining deviance could in part be attributed to differences between Camponotus colonies ( $\mathrm{p}=0.04)$, whereas

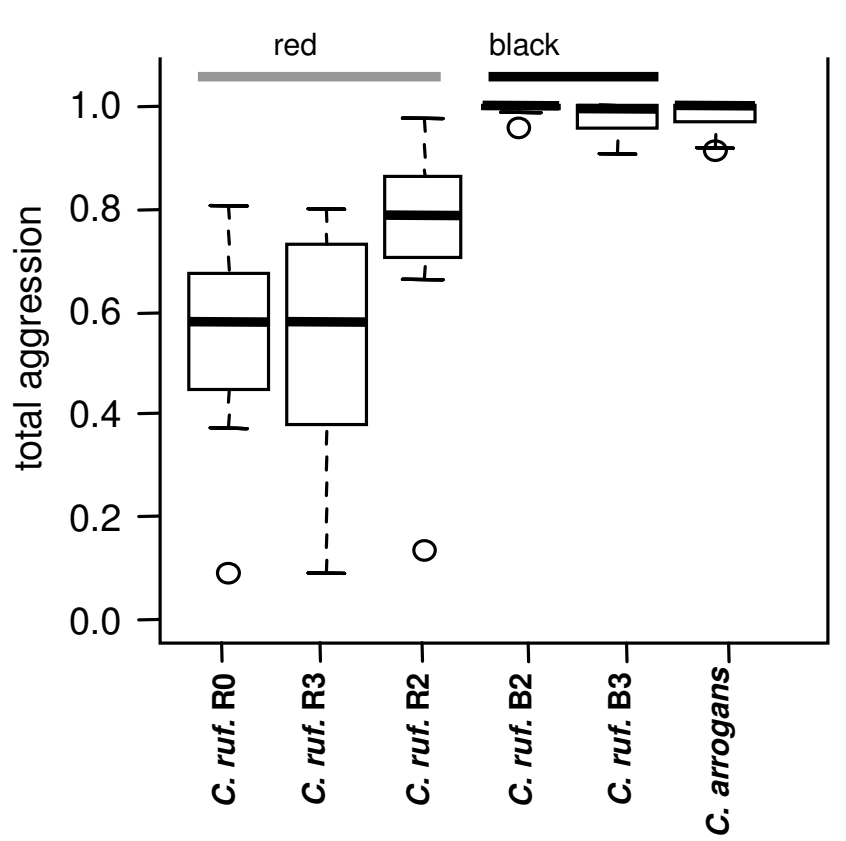

Figure 3

Total aggression of Crematogaster modiglianii (colony R0) against different Camponotus colonies and species. Data are given as proportions in relation to the total number of interactions. Each plot represents 10 replicates.

the difference between intracolonial and allocolonial Camponotus was not significant $(\mathrm{p}=0.12$, Table 4$)$. The non-parabiotic Camponotus (Tanaemyrmex) arrogans was attacked to a similar degree as the black $\mathrm{Ca}$. rufifemur variety (Figure 3). When the analysis focused on the proportion of strong aggression only, the results were similar, with slightly stronger effects. Cr. modiglianii very rarely climbed onto the Ca. rufifemur bodies in this experimental series ('mounting behaviour').

In the arena confrontations, $\mathrm{Cr}$. modiglianii was significantly more aggressive towards $\mathrm{Ca}$. rufifemur from the respective other variety. The parameter 'within/across variety' explained $18.2 \%$ of the total deviance, followed by

Table 4: GLM for total aggression of Cr. modiglianii towards dead Ca. rufifemur workers from different colonies.

\begin{tabular}{lrrrl}
\hline Parameter & Deviance & df & $\boldsymbol{F}$ & $\boldsymbol{P}$ \\
\hline Ca. rufifemur variety & 735.3 & $\mathrm{I}$ & 74.16 & $<0.000 \mathrm{I}$ \\
Ca. rufifemur colony & 62.8 & 2 & 3.45 & 0.040 \\
intra-/allocolonial & 24.7 & $\mathrm{I}$ & 2.53 & 0.12 \\
residual error & 430.0 & 46 & & \\
total & 1252.9 & 50 & &
\end{tabular}

Data from behavioural experiments with a $\mathrm{Cr}$. modiglianii laboratory colony. ' $C a$. rufifemur colony' is nested within ' $C a$. rufifemur variety'. 
'variety combination' (13.0\% explained deviance), while 'intra-/allocolonial' did not explain a significant part of the deviance (Table 5). Cr. modiglianii workers frequently climbed on Ca. rufifemur bodies and walked around on them for up to one minute. This 'mounting behaviour' represented on average $18.6 \%$ of all interactions (Figure $4)$. The workers (especially in one of the two colonies) mounted $\mathrm{Ca}$. rufifemur workers of their 'own' variety in significantly higher proportions (GLM for both colonies: $\mathrm{F}_{\mathrm{df}=1}=6.85, \mathrm{p}=0.011$ ) but did not otherwise differentiate between intracolonial and allocolonial Ca. rufifemur workers $\left(F_{d f=1}=0.14, p=0.71\right)$.

In order to examine whether the differentiation between the colour varieties occurred in colonies in situ as well, we re-analyzed previous behavioural experiments reported in [2]. Allocolonial aggression of $\mathrm{Cr}$. modiglianii towards $\mathrm{Ca}$. rufifemur was highly variable in this dataset, and we confirmed a high impact of the two chemical varieties on allocolonial aggression. The variable 'within/across varieties' (colonies A and B: black variety, colony C: red variety) explained $60.1 \%$ of the total variance of the data and was a clearly more powerful predictor than the differentiation between intra- vs. allocolonial combination $(0.03 \%$ deviance explained, Table 6). 'Red' Cr. modiglianii colonies only attacked black $\mathrm{Ca}$. rufifemur intruders and vice versa (Figure 5a). The highly significant impact of 'variety combination' (Table 6), however, showed that red Cr. modiglianii was more aggressive towards black Ca. rufifemur than black $\mathrm{Cr}$. modiglianii towards red $\mathrm{Ca}$. rufifemur.

In confrontations of Ca. rufifemur towards allocolonial $\mathrm{Cr}$. modiglianii, Menzel et al. [2] had found low levels of aggression albeit they were higher than against intracolonial Cr. modiglianii. Similar to above, Ca. rufifemur workers were more aggressive towards $\mathrm{Cr}$. modiglianii from the respective other variety (Figure 5b, Table 6 ).

\section{Discussion \\ Unusual features of the cuticular profiles in parabiotic ants}

To our knowledge, steroids have not been found in surface extracts of other ant species up to now, and to our knowledge have been found on insect cuticles only in one halictid bee [30]. However, various Crematogaster species are known to have highly efficient poisons $[31,32]$. The genus Crematogaster has evolved a peculiar system of venom production which involves a cooperation of Dufour and poison gland. In several species the venom consists of precursors from the Dufour gland which are derivatized by enzymes from the poison gland [33,34]. Crematogaster poisons - from Dufour and poison glands, but also from hypertrophied metapleural glands - belong to such different chemical classes as cyclohexan derivatives, crematofuranes (cembranoid diterpenes), coumarin derivatives, alkylphenols, alkylresorcinols, salicylic acids, resorcylic acids, and polyfunctionalized long-chain derivatives [33,35-38]. Since extracts of $\mathrm{Cr}$. modiglianii Dufour glands contained the same steroid composition as the body surface (but no other compounds), they are probably produced in this gland and then distributed onto the body surface. In Cr. modiglianii, steroid synthesis did not depend on biosynthetic precursors acquired from food. In two colonies kept in the laboratory for 15 and 6 months, respectively, the steroid profile did not change despite of an artificial diet of cockroaches, honey solution and Bhatkar diet (F.M. pers. obs.). Moreover, in one forest colony, the steroid profile remained relatively constant over three years, corroborating that the steroid composition is rather genetically determined than dependent on environmental factors.

It is notable that $98 \%$ of the entire hydrocarbon profile of the red Ca. rufifemur (and $\geq 13 \%$ of the black Ca. rufifemur hydrocarbon profile) were methyl-branched alkenes. This substance class seems to be generally very rare in insects and has been detected only in several Diptera and one Noctuid moth as pheromones [39-41]. Among ants, they have been found in traces in the ponerine ant Pachycondyla villosa and in two Leptothorax species [42,43], but in higher abundances only in Nothomyrmecia macrops surface profiles, which is probably the most primitive existent ant species [44]. That they make up almost the entire hydrocarbon profile is therefore highly unusual. Another unusual feature in both parabiotic species is the high hydrocarbon chain lengths. Although common in this study (Table 1), hydrocarbons beyond $\mathrm{C}_{37}$ have not been found in non-parabiotic Camponotus and Crematogaster species $[9,27,28]$; unpublished data. Other studies report small concentrations of heavier hydrocarbons in other ant genera, but always accompanied by high amounts of lighter ones $[45,46]$. It is possible that extremely longchain hydrocarbons are difficult to perceive by receptors and thus promote interspecific tolerance $[23,47]$. In one case, we observed that a non-parabiotic Cr. modiglianii colony was initially very aggressive against (black) $C a$. rufifemur workers but treated them amicably (and had hence become habituated) after less than $24 \mathrm{~h}$ of exposure. Unsaturation in these long-chain hydrocarbons might be necessary to maintain a minimum fluidity of the cuticular profile [47].

\section{Chemical overlap among parabiotic partners}

Given the high allocolonial tolerance between parabiotic partners, the hydrocarbon overlap of the two species is surprisingly small. While the red Ca. rufifemur variety shared two compounds with its partner, the black variety only shared three trace compounds with $\mathrm{Cr}$. modiglianii but otherwise possessed a completely different hydrocarbon profile. We tentatively suppose that $\mathrm{Cr}$. modiglianii 


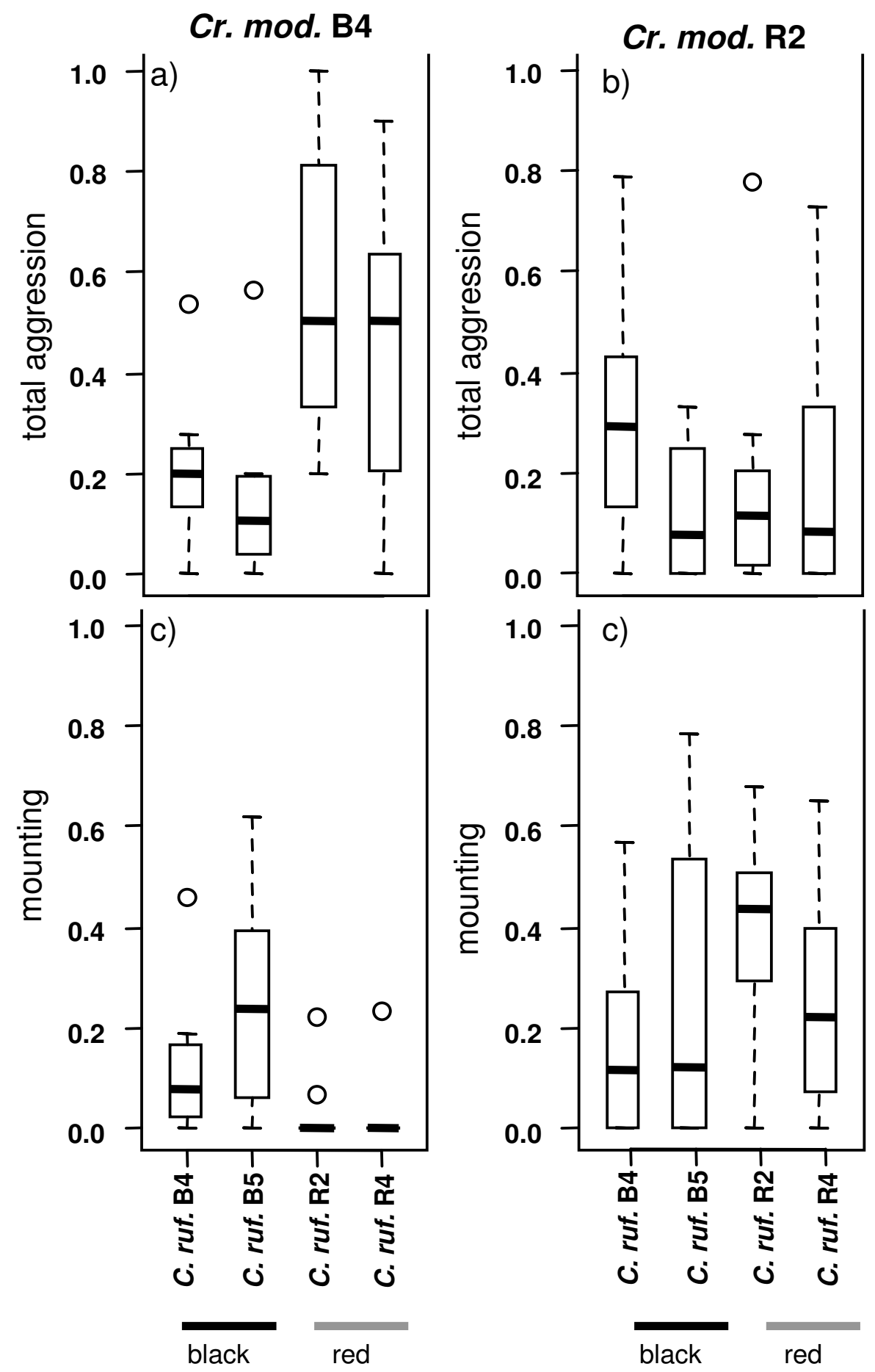

Figure 4

Total aggression (a, b) and mounting behaviour (c, d) of Cr. modiglianii towards dead Ca. rufifemur from different colonies in arena assays. Data are given as proportions in relation to the total number of interactions. Each plot represents I0-13 replicates. (a), (c) Cr. Modiglianii B4, (b), (d) Cr. modiglianii R2. 
Table 5: GLM for total aggression of Cr. modiglianii towards dead Ca. rufifemur from different colonies.

\begin{tabular}{lrrrl}
\hline Parameter & Deviance & df & $\boldsymbol{F}$ & $\boldsymbol{P}$ \\
\hline within/across varieties & 107.8 & $\mathrm{I}$ & 20.64 & $<0.000 \mathrm{I}$ \\
variety combination & 77.3 & 2 & 8.19 & 0.00056 \\
colony combination & 37.0 & 3 & 2.76 & 0.048 \\
intra-/allocolonial & 0.2 & $\mathrm{I}$ & 0.05 & 0.83 \\
residual error & 370.6 & 80 & & \\
total & 592.9 & 87 & & \\
& & & & \\
\hline
\end{tabular}

Data from arena confrontations with Cr. modiglianii. 'Variety combination' ist nested within the parameter 'within/across varieties'. 'Colony combination' is nested within 'variety combination'. Due to this nested structure, no interactions between the variables occur.

acquires 27-MeC39-14-ene 27-MeC39-16-ene from its red $\mathrm{Ca}$. rufifemur partner although $\mathrm{Ca}$. rufifemur generally tolerates $\mathrm{Cr}$. modiglianii workers, including those lacking these substances [2]. In a Cr. modiglianii colony kept in the laboratory without its previous red Camponotus partner, the compound disappeared from the profile after eight months of separation (F.M. pers. obs.). It is possible that the other hydrocarbons of the red $\mathrm{Ca}$. rufifemur are acquired by $\mathrm{Cr}$. modiglianii as well but remain beyond detectability due to their low abundances. The hydrocarbons of the black Ca. rufifemur, in contrast, were never found on Cr. modiglianii surface extracts. This is probably due to their high chain lengths, which makes the cuticular profile more solid and do not allow chemical transfer [47]. In the light of the low overall hydrocarbon overlap among the two parabiotic ant species, chemical camouflage, a mechanism often found in social parasites [1315], must be dismissed as an explanation for mutual tolerance. However, the existence of only few substances common to both species might be a sufficient signal for tolerating the partner [48].

The steroid components, in contrast, showed high congruence among both species. We found that the relative composition of eight steroid compounds differs between colonies but is very similar among the two species of a parabiotic nest. Since it is highly improbable that $\mathrm{Ca}$. rufifemur is able to synthetically copy the steroid profile of each respective partner colony, this result suggests that $\mathrm{Ca}$. rufifemur acquires steroids from $\mathrm{Cr}$. modiglianii. Notably, only a certain set of steroids is transferred to Camponotus, while others, despite of high abundance in $\mathrm{Cr}$. modiglianii, were almost or completely absent from the Ca. rufifemur profile.

\section{Possible transfer mechanisms}

Two mechanisms seem possible for the observed transfer of chemical cues, namely trophallaxis and direct physical contact. Via trophallaxis, individual ants exchange not only food but also the PPG content, i.e. hydrocarbons rel- evant for nestmate recognition [49]. The PPG of Cr. modiglianii indeed contained steroids, albeit in much lower concentrations than on the body surface, thus making trophallaxis a possible pathway for chemical transfer. Interspecific trophallaxis has been observed between the two parabiotic species (F.M. and A. Endler, pers. obs.) and also shown via stained food only fed to $\mathrm{Cr}$. modiglianii (F.M., pers. obs.).

Another possible transfer mechanism is direct physical contact. We frequently observed that $\mathrm{Cr}$. modiglianii climbed on living or dead Ca. rufifemur individuals (workers and alates). The latter sometimes tried to shake them off but did not show aggression. Though almost never observed in the field, this 'mounting behaviour' could be easily induced in the laboratory by keeping the two species separate for one or two days. Mounting may therefore represent another possible mechanism for transfer of surface chemicals.

\section{Partner recognition is not colony-specific}

The red and the black variety of Camponotus rufifemur are chemically distinct and - apart from trace compounds do not share any hydrocarbons. The two dominant surface components of the red variety (substance \#52, Table 1) are present in Crematogaster modiglianii colonies associated with this $\mathrm{Ca}$. rufifemur variety but almost completely absent from those living with the black variety. Their abundance thus allows separating 'red' from 'black' $\mathrm{Cr}$. modiglianii albeit the remaining surface profile is similar. The existence of two chemical $\mathrm{Ca}$. rufifemur varieties accounts for most of the aggression variance in allocolonial encounters between the two species. $\mathrm{Cr}$. modiglianii usually tolerated living or dead $\mathrm{Ca}$. rufifemur workers of the same variety as their parabiotic partner but fiercely attacked those of the respective other variety (Figures 3, 4, 5 , Tables 4, 5, 6). An analogous pattern was found in $\mathrm{Ca}$. rufifemur. Despite of generally low aggression levels, black $\mathrm{Ca}$. rufifemur workers were significantly more aggressive towards 'red' $\mathrm{Cr}$. modiglianii workers than towards allocolonial 'black' Cr. modiglianii (Figure 5b). However, we did not detect a corresponding difference in the red Ca. rufifemur.

While much of the interspecific aggression can be explained by chemical differences, however, the low interspecific aggression within chemical varieties is still surprising. Rather than recognizing heterospecific nestmates, the two species seemingly recognize only the chemical variety of their partner and do not discriminate within these varieties. Nestmate recognition rather depends on volatile substances than on substances only perceivable through antennal contact [50]. Due to their low volatility [47], very long-chain hydrocarbons are less detectable than short-chain molecules. Thus, olfactory receptors may 


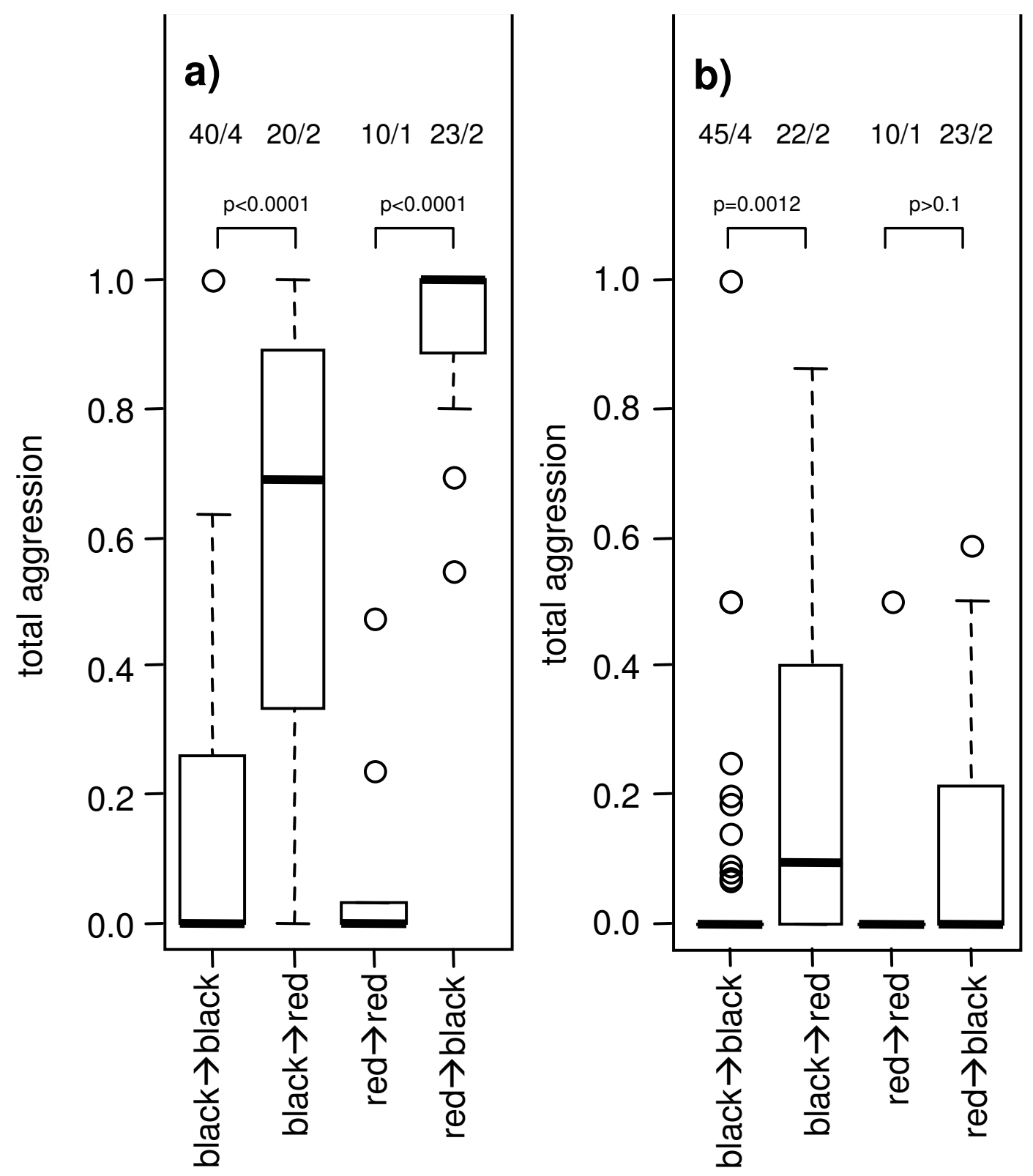

Figure 5

Total aggression in allocolonial confrontations between parabiotic partners assays, pooled for variety combinations. Data are from [2], given as proportions in relation to the total number of interactions. The numbers above each plot indicate the overall number of replicates and the number of colony combinations tested. P values are given according to GLMs with binomial error distribution. (a) Cr. modiglianii towards Ca. rufifemur, (b) Ca. rufifemur towards Cr. modiglianii.

additionally absorb traces of lighter hydrocarbons, thereby blurring inter-colony profile differences and hampering inter-colony discrimination [23]. The role of the steroids in the nestmate discrimination process is still unclear and under investigation.
The high interspecific tolerance strongly contrasts with the South American parabioses of Crematogaster limata and the ponerine ant Odontomachus mayi, where the ants never tolerated heterospecific workers from foreign parabioses [3]. In these associations, very low chemical overlap was found (no substance data given), suggesting that both 
Table 6: GLM for total aggression in interspecific live confrontations

\begin{tabular}{|c|c|c|c|c|c|c|c|c|}
\hline & \multicolumn{4}{|c|}{ Cr. modiglianii $\rightarrow$ Ca. rufifemur } & \multicolumn{4}{|c|}{ Ca. rufifemur $\rightarrow C r$. modiglianii } \\
\hline & Deviance & $d f$ & $F$ & $P$ & Deviance & $d f$ & $F$ & $\bar{P}$ \\
\hline within/across varieties & 674.3 & I & 124.56 & $<0.0001$ & 45.2 & I & 13.09 & 0.00047 \\
\hline variety combination & 79.4 & 2 & 9.19 & 0.0002 & 5.6 & 2 & 0.81 & 0.45 \\
\hline intra-/allocolonial & 0.3 & 1 & 0.07 & 0.79 & 0.0 & 1 & 0.00 & 0.99 \\
\hline colony combination & 18.0 & 4 & 1.01 & 0.41 & 12.4 & 4 & 0.99 & 0.42 \\
\hline No. Camponotus & 1.4 & I & 0.32 & 0.57 & 0.0 & I & 0.00 & 0.96 \\
\hline No. Crematogaster & 2.1 & I & 0.47 & 0.49 & 5.2 & 1 & 1.73 & 0.19 \\
\hline residual error & 346.0 & 82 & & & 260.5 & 89 & & \\
\hline total & 1121.5 & 92 & & & 328.9 & 99 & & \\
\hline
\end{tabular}

Data from [2]. 'Colony combination' is nested within 'variety combination'. There are no interactions between the variables due to their nested structure.

species habituated to each other's colony-specific profiles. The associated Chilean species Camponotus morosus and Solenopsis gayi also showed distinct hydrocarbon profiles [51]. In contrast to non-associated colonies, however, associated C. morosus had acquired small amounts of the $S$. gayi hydrocarbons. In both of these species, only individuals from associated colonies were tolerant towards allocolonial allospecifics [51], indicating that the acquisition of allospecific hydrocarbons promoted mutual tolerance.

\section{Conclusion}

In this study we document the cuticular chemistry of the parabiotically associated ant species Camponotus rufifemur and Crematogaster modiglianii. In contrast to neotropical parabioses, these ant species did not show heterospecific nestmate recognition. In our experiments, $\mathrm{Cr}$. modiglianii did not discriminate its partner Ca. rufifemur colony from other $\mathrm{Ca}$. rufifemur colonies of the same chemical variety (nor vice versa). Rather, Cr. modiglianii distinguished only between the two $\mathrm{Ca}$. rufifemur varieties, accepting the familiar one but attacking the respective other. This reduced discrimination of heterospecific nestmates may be caused by two unusual properties of the cuticular surface: Transfer of $\mathrm{Ca}$. rufifemur hydrocarbons to the $\mathrm{Cr}$. modiglianii profile (in one of the Ca. rufifemur varieties only), and the generally high chain hydrocarbon lengths in the two parabiotic species. As hypothesized elsewhere [23], extremely long-chain hydrocarbons may be difficult to perceive by receptors and hence promote chemical insignificance (sensu [1]). It is currently investigated whether the cuticular steroids unique to these species play a role in nestmate or partner recognition.

\section{Methods}

\section{Study site and ants}

The studies were conducted at Danum Valley Conservation Area from September to November in the years 2004 and 2007. Danum Valley represents one of the major remaining patches of tropical lowland rainforest in Sabah
(Malaysian Borneo). The site has a typical equatorial rainforest climate with a mean annual temperature of $26.9^{\circ} \mathrm{C}$ and a yearly rainfall of $2700 \mathrm{~mm}$. We studied parabiotic associations of Camponotus (Myrmotarsus) rufifemur Emery 1900 and Crematogaster (Paracrema) modiglianii Emery 1900. Their nests are commonly found in hollow, living tree trunks in the rainforest. Extracts of one parabiotic nest from the Kuala Belalong Field Studies Center (Brunei) were analyzed in addition.

Camponotus rufifemur occurs in two sympatric morphological varieties that have not previously been described (although Emery [52] notes that specimen from Sarawak are darker in colour than those from Sumatra). While one variety (henceforth, 'red' variety) has a reddish alitrunk and light red-brown legs, the other one (henceforth, 'black' variety) possesses a black alitrunk and dark redbrown legs. The area between the frontal carinae of soldiers is dull in the red but shining in the black variety. Although the ratio head width/scape length (in frontal view) tends to be higher in the large soldier caste of the black variety than in that of the red variety, no significant morphometric differences were found. In the following, we will refer to the varieties as 'red' and 'black' Ca. rufifemur. In order to allow a differentiation, the respective associated $\mathrm{Cr}$. modiglianii will be called 'red' and 'black' $\mathrm{Cr}$. modiglianii although we did not find morphological distinctions within this species. Voucher specimen of $\mathrm{Cr}$. modiglianii and both Ca. rufifemur varieties are deposited at the Department of Zoology III, University of Würzburg and at the Forest Resarch Center in Sepilok, Sabah (Malaysia).

\section{Preparation of extracts}

Extracts were prepared from both body surface and postpharyngeal glands (PPGs). For body rinses, 10 to 90 ants were killed by freezing and immersed in hexane for ten minutes. Extracts from single individuals contained quantities too low for reliable substance identification. Eleven parabiotic nests were sampled with one to eight (mean: 
3.5) replicates per colony and species (ten from Danum Valley, one from Kuala Belalong). PPG extracts were obtained from three to four freshly dissected PPGs per sample dissolved in hexane. Octadecane $\left(n-C_{18}\right)$ was used as internal standard in most samples. Cuticular substances were additionally obtained from living $\mathrm{Cr}$. modiglianii workers brought into the laboratory in Würzburg with solid-phase microextraction (SPME). A SPME fibre (Supelco) coated with a $100 \mu \mathrm{m}$ polydimethylsiloxan film was rubbed on the ant for 3 min and then directly injected into a ThermoQuest Trace GC.

\section{Chemical analysis}

Substances were identified by coupled capillary gas chromatography-mass spectrometry (GC-MS) with a Hewlett Packard 6890 series gas chromatograph coupled to a HP 5973 Mass Selective Detector. The GC was equipped with a J\&W Scientific DB-5 fused silica capillary column (30 m $\times 0.25 \mathrm{~mm}$ ID; $\mathrm{df}=0.25 \mu \mathrm{m})$. Temperature was kept at $60^{\circ} \mathrm{C}$ for $2 \mathrm{~min}$ then increased by $60^{\circ} \mathrm{C} / \mathrm{min}$ up to $200^{\circ} \mathrm{C}$ and subsequently by $4^{\circ} \mathrm{C} / \mathrm{min}$ to $320^{\circ} \mathrm{C}$, where it remained constant for $10 \mathrm{~min}$. Helium was used as carrier gas with a constant flow of $1 \mathrm{ml} / \mathrm{min}$. A split/splitless injector was installed at $250^{\circ} \mathrm{C}$ in the splitless mode for 30 s. The electron impact mass spectra (EI-MS) were recorded with an ionisation voltage of $70 \mathrm{eV}$, a source temperature of $230^{\circ} \mathrm{C}$ and an interface temperature of $325^{\circ} \mathrm{C}$. For analysis of hydrocarbons beyond $\mathrm{C} 41$, we used a DB- 1 HT column $(30 \mathrm{~m} \times 0.25 \mathrm{~mm} \mathrm{ID;} \mathrm{df}=0,25$ $\mu \mathrm{m})$. Temperature was raised from $60^{\circ} \mathrm{C}$ by $5^{\circ} \mathrm{C} / \mathrm{min}$ up to $350^{\circ} \mathrm{C}$ and then kept constant for $10 \mathrm{~min}$. The interface had a temperature of $350^{\circ} \mathrm{C}$. All other settings were as above. The software MSD ChemStation (Version A.03.00) for Windows was used for data acquisition. We restricted the analyses to substances with a retention time beyond that of C19 since compounds with shorter chain length are likely to be too volatile to be relevant for nestmate recognition [5,6]. Substances present in less than $50 \%$ of the samples are given in Table 1 (marked with ${ }^{*}$ ) but were disregarded from further analysis.

For quantification of steroid-like compounds and aliphatics shorter than $\mathrm{C}_{33}$, we used ion counts from the GC-MS data and analysed both substance classes separately. Heavier hydrocarbons (beyond C33) were quantified using a high-resolution ThermoQuest Trace GC-FID with $\mathrm{H}_{2}$ as carrier gas in order to achieve a better separation of the substances. We used a nonpolar capillary column [DB1 (J\&W Scientific, Folsom, CA), $20 \mathrm{~m} \times 0.18 \mathrm{~mm}, 0.18$ $\mu \mathrm{m}$ film thickness] and the first temperature program given above (split closed for $30 \mathrm{~s}$ for extracts and for $2 \mathrm{~min}$ when using SPME fibers). The split/splitless injector port was kept at $260^{\circ} \mathrm{C}$ and the flame ionization detector (FID) at $340^{\circ} \mathrm{C}$. Peak areas were computed with ChromCard 1.19 (CE Instruments, Milan, Italy). Mean absolute substance quantities were estimated by comparing substance peak areas with that of the internal standard (acquired with GC-FID) and dividing by the number of extracted individuals.

Profile similarities between the two partner species were analyzed for eleven parabiotic nests (including one from Kuala Belalong Field Studies Center). The average proportions of the steroid components per colony and species were calculated. The distances between colonies were calculated for each species separately using Bray-Curtis index of similarity and then compared between species using a Mantel test (1000 permutations).

\section{Identification of cuticular hydrocarbons}

Alkanes, methyl-branched alkanes and alkenes were characterized using diagnostic ions and retention indices calculated using Kovats' method [53]. Unsaturated methylbranched hydrocarbons were hydrated under a $\mathrm{H}_{2}$ atmosphere using Palladium on activated carbon as catalyst to determine the position of the methyl group. The position of the double bond in methyl-branched and n-alkenes was determined using DMDS derivatization following [54]. For methyl-branched alkenes, DMDS derivatization was insufficient for substance characterization since the position of the double bond relative to the methyl group remained unresolved and left two possible structures. Therefore, we cleaved the molecules in two parts at the position of the double bond via ozonisation. We diluted the sample in approx. $3 \mathrm{ml}$ hexane, applied a constant flow of $\mathrm{O}_{3}(300 \mathrm{mg} / \mathrm{h})$ for ten minutes from a glass pipette (EO3G Ozone Generator, Easelec Technology Inc.) and directly injected the sample into the GC-MS. Ozonisation succeeded for substance 52 but not for the substances 37, 43, 56, and 61 (surface compounds of the red Ca. rufifemur, Table 1). However, it is highly probable that all methyl-branched alkenes are produced via the same biosynthetic pathway. We therefore tentatively inferred the position of the double bond from the structure of substances 52 (Table 1) and possibilities left from the DMDS results, which had succeeded for all of the above substances. Double bond positions in alkenes with chain lengths higher than $\mathrm{C} 41$ as well as in dienes and trienes could not be determined due to their low abundance and/ or their high chain length, which resulted in derivatives which could not be detected using GC-MS. Aldehydes were identified by comparing their mass spectra to a commercial library (Wiley 275) and therefore remain tentative.

For the substances of the black Ca. rufifemur profile beyond $\mathrm{C} 44$, retention indices were calculated based on the retention times of an n-alkane standard (C21 to C40), $\mathrm{C} 47$ and $\mathrm{C} 49$, and therefore remain preliminary. These substances were identified based on mass spectra and 
hydrated samples. Unsaturation was further confirmed via fractionation using a $\mathrm{SiOH}$ column treated with $\mathrm{AgNO}_{3}$. However, their characterization remains preliminary since the DMDS derivatized substances could not be detected using GC-MS.

\section{Behavioural experiments}

We studied the reaction of Crematogaster modiglianii towards dead $\mathrm{Ca}$. rufifemur workers from different colonies in Borneo. The reverse situation ( $\mathrm{C} a$. rufifemur towards $C r$. modiglianii) was not studied in this paper since $C a$. rufifemur shows little discrimination between different Cr. modiglianii workers [2]. A Cr. modiglianii colony (R0) had been collected in the forest circa one week prior to the experiments and was kept together with its red Ca. rufifemur partner in its original nest (a small tree trunk) in an open plastic box. The dead ants were placed onto the nest trunk with forceps such that several ants could interact with it simultaneously. During three minutes, each observed interaction was classified as peaceful (antennating), weakly (open mandibles) or strongly aggressive (biting or locking mandibles). An additional behaviour classified as peaceful was 'mounting', where the smaller Crematogaster (body length approx. 2-3 mm) climbed onto the Camponotus body (body length 5-13 $\mathrm{mm})$. Continued interactions were recorded again after 10 $s$ (the same behavioural classification as used in [2]).

The aggressiveness of two other Cr. modiglianii colonies was estimated in arena confrontations. The workers had been collected in the forest one day prior to the tests and were kept in a plastic box among nestmates (but separate from the partner species) over night. Five Cr. modiglianii individuals were placed into a fluon-covered plastic cylinder $(\varnothing 7.5 \mathrm{~cm}$, height $5 \mathrm{~cm})$ on top of a paper sheet floor. After 1 min to calm down, a dead Camponotus specimen was introduced. For the following $100 \mathrm{~s}$ we recorded the behaviour of the ants as above. Each living or dead ant was used for one assay only. In all of the above assays, we performed ten replicates per treatment.

From each replicate we calculated the proportions of all aggressive versus all non-aggressive interactions. Both strong and total (including weak) aggression were analyzed using generalized linear models (GLM) with quasibinomial error distribution and logit link function. In order to determine whether confrontations within and across chemical varieties differ, we used the according explanatory variable 'within/across variety' with two factor levels (which collapsed to 'Camponotus variety' in the first dataset). The variable 'variety combination' (with the factor levels 'black $\rightarrow$ black', 'black $\rightarrow$ red', 'red $\rightarrow$ red', and 'red $\rightarrow$ black') was nested in the former one. Further explanatory variables were 'colony combination' (nested in 'variety combination'), which collapsed to 'Camponotus colony' in the first dataset, and 'intra-/allocolonial'. Due to their nested structure, no interactions between the variables were possible. The impact of each variable was determined by likelihood ratio tests (F tests). We also reanalyzed data from [2] in a similar way, where we included the number of workers present in the experimental arena as explanatory variables (see [2] for details on the experimental setup). Since the statistical results for total aggression and for strong aggression only were similar, only the former will be reported in the results section. All computations were performed in R Version 2.5.1 [55].

\section{Competing interests}

The authors declare that they have no competing interests.

\section{Authors' contributions}

NB conceived the study and designed the experimental setup. FM collected the samples, performed the quantitative analysis of the cuticular substances, the behavioural experiments and the statistical analyses and wrote the manuscript. TS contributed significantly to the concept and the design of the study and identified the cuticular substances. Both NB and TS contributed to the preparation of the manuscript. All authors read and approved the final manuscript.

\section{Acknowledgements}

We thank Annett Endler and Heike Feldhaar for support regarding chemical analyses. Brigitte Fiala kindly provided samples from Brunei for further analysis. We are grateful to the Danum Valley Management Committee (DVMC) and Malaysian Economic Planning Unit (EPU) for research permission, the Royal Society's South East Asia Rainforest Research Programme (SEARRP) and the staff at Danum Valley Field Center, especially Bernadus 'Mike' Bala Ola for logistic support and help in the field. Dr. Arthur Chung (Forest Research Center, Sepilok) kindly supported our work as local collaborator. Finally, we would like to thank three anonymous reviewers for helpful comments on the manuscript. This research was supported by the Sonderforschungsbereich 'Mechanisms and Evolution of Arthropod Behaviour' (SFB-554) of the German Research Foundation (DFG) and complies with current laws of Malaysia and Germany. F.M. was supported by a doctoral fellowship provided by the German National Academic Foundation (Studienstiftung des deutschen Volkes) and the Bayerische Graduiertenförderung.

\section{References}

I. Lenoir A, D'Ettorre P, Errard C, Hefetz A: Chemical Ecology and Social Parasitism in Ants. Annual Review of Entomology 200I, 46:573-599.

2. Menzel F, Linsenmair KE, Blüthgen N: Selective interspecific tolerance in tropical Crematogaster-Camponotus associations. Animal Behaviour 2008, 75:837-846.

3. Orivel J, Errard C, Dejean A: Ant gardens: Interspecific recognition in parabiotic ant species. Behavioral Ecology and Sociobiology 1997, 40:87-93.

4. Hölldobler B, Wilson EO: The Ants Berlin, Heidelberg: Springer Verlag; 1990.

5. Vander Meer RK, Morel L: Nestmate Recognition in Ants. In Pheromone communication in social insects. Ants, wasps, bees, and termites Edited by: Vander Meer RK, Breed MD, Espelie KE, Winston ML. Boulder: Westview Press; 1998:79-103.

6. Lenoir A, Malosse C, Yamaoka R: Chemical mimicry between parasitic ants of the genus Formicoxenus and their host Myr- 
mica (Hymenoptera, Formicidae). Biochemical Systematics and Ecology 1997, 25:379-389.

7. Lahav S, Soroker V, Hefetz A: Direct behavioral evidence for hydrocarbons as ant recognition discriminators. Naturwissenschaften 1999, 86:246-249.

8. Wagner D, Tissot M, Cuevas W, Gordon DM: Harvester ants utilize cuticular hydrocarbons in nestmate recognition. Journal of Chemical Ecology 2000, 26:2245-2257.

9. Boulay R, Hefetz A, Soroker V, Lenoir A: Camponotus fellah colony integration: worker individuality necessitates frequent hydrocarbon exchanges. Animal Behaviour 2000, 59: I I27-I I 33 .

10. Boulay R, Katzav-Gozansky T, Hefetz A, Lenoir A: Odour convergence and tolerance between nestmates through trophallaxis and grooming in the ant Camponotus fellah (Dalla Torre). Insectes Sociaux 2004, 5 I:55-6I.

II. Soroker V, Vienne C, Hefetz A, Nowbahari E: The Postpharyngeal Gland as a "Gestalt" Organ for Nestmate Recognition in the Ant Cataglyphis niger. Naturwissenschaften 1994, 8 I:5 I 0-5 I3.

12. Errard C, Hefetz A, Jaisson P: Social discrimination tuning in ants: template formation and chemical similarity. Behavioral Ecology and Sociobiology 2006, 59:353-363.

13. Akino T: Chemical camouflage by myrmecophilous beetles Zyras comes (Coleoptera: Staphylinidae) and Diaritiger fossulatus (Coleoptera: Pselaphidae) to be integrated into the nest of Lasius fuliginosus (Hymenoptera: Formicidae). Chemoecology 2002, I 2:83-89.

14. Akino T, Knapp JJ, Thomas JA, Elmes GW: Chemical mimicry and host specificity in the butterfly Maculinea rebeli, a social parasite of Myrmica ant colonies. Proceedings of the Royal Society of London, Series B 1999, 266:1419-1426.

15. Akino T, Mochizuki R, Morimoto M, Yamaoka R: Chemical camouflage of myrmecophilous cricket Myrmecophilus. sp to be integrated with several ant species. Japanese Journal of Applied Entomology and Zoology 1996, 40:39-46.

16. Howard RW, Stanley-Samuelson DW, Akre RD: Biosynthesis and chemical mimicry of cuticular hydrocarbons from an obligate predator, Microdon albicomatus Novak (Diptera: Syrphidae) and its ant prey, Myrmica incompleta Provancheri (Hymenoptera: Formicidae). Journal of the Kansas Entomological Society 1990, 63:437-443.

17. Dronnet S, Simon X, Verhaeghe J-C, Rasmont P, Errard C: Bumblebee inquilinism in Bombus (Fernaeldaepsithyrus) sylvestris (Hymenoptera, Apidae): behavioural and chemical analyses of host-parasite interactions. Apidologie 2005, 36:59-70.

18. Elgar MA, Allan RA: Predatory spider mimics acquire colonyspecific cuticular hydrocarbons from their ant model prey. Naturwissenschaften 2004, 91 : 143-147.

19. Howard RW, Perez-Lachaud G, Lachaud JP: Cuticular hydrocarbons of Kapala sulcifacies (Hymenoptera: Eucharitidae) and its host, the ponerine ant Ectatomma ruidum (Hymenoptera: Formicidae). Annals of the Entomological Society of America 200I, 94:707-7I6.

20. D'Ettorre P, Mondy N, Lenoir A, Errard C: Blending in with the crowd: social parasites integrate into their host colonies using a flexible chemical signature. Proceedings of the Royal Society of London, Series B 2002, 269:1911-1918.

21. Jeral JM, Breed MD, Hibbard BE: Thief ants have reduced quantities of cuticular compounds in a ponerine ant, Ectatomma ruidum. Physiological Entomology 1997, 22:207-2II.

22. Akino $\mathrm{T}$ : Cuticular hydrocarbons of Formica truncorum (Hymenoptera: Formicidae): Description of new very long chained hydrocarbon components. Applied Entomology and Zoology 2006, 4I:667-677.

23. Lambardi D, Dani FR, Turillazzi S, Boomsma J]: Chemical mimicry in an incipient leaf-cutting ant social parasite. Behavioral Ecology and Sociobiology 2007, 61:843-85I.

24. Errard C, Regla Jl, Chambris A: Interspecific recognition in chilean parabiotic ant species. In Presented at 3rd Jornadas Chile Francia di Etologia e Sociobiologia Universidad Mayor, Santiago, Chile; 1996.

25. Liu ZB, Yamane S, Yamamoto H, Wang QC: Nestmate discrimination and cuticular profiles of a temporary parasitic ant Lasius sp. and its host $L$. fuliginosus (Hymenoptera, Formicidae). Journal of Ethology 2000, 18:69-73.

26. Liu ZB, Bagneres AG, Yamane S, Wang QC, Kojima J: Cuticular hydrocarbons in workers of the slave-making ant Polyergus samurai and its slave, Formica japonica (Hymenoptera: Formicidae). Entomological Science 2003, 6: I 25-133.

27. Boulay R, Katzav-Gozansky T, Vander Meer RK, Hefetz A: Colony insularity through queen control on worker social motivation in ants. Proceedings of the Royal Society of London, Series B 2003, 270:97।-977.

28. Endler A, Liebig J, Schmitt T, Parker JE, Jones GR, Schreier P, Hölldobler B: Surface hydrocarbons of queen eggs regulate worker reproduction in a social insect. Proceedings of the National Academy of Sciences of the United States of America 2004, I 01 :2945-2950.

29. Meskali M, Bonavitacougourdan A, Provost E, Bagneres AG, Dusticier G, Clement JL: Mechanism underlying cuticular hydrocarbon homogeneity in the ant Camponotus vagus (Scop) (Hymenopters, Formicidae) - role of postpharyngeal glands. Journal of Chemical Ecology 1995, 2 I: I | 27- | | 48.

30. Ayasse M, Engels W, Lübke G, Taghizadeh T, Francke W: Mating expenditures reduced via female sex pheromone modulation in the primitively eucosial halictine bee, Lasioglossum (Evylaeus) malachurum (Hymenoptera: Halictidae). Behavioral Ecology and Sociobiology 1999, 45:95-106.

3I. Heredia A, De Bizeau JC, Quinet Y: Toxicity of the venom in three neotropical Crematogaster ants (Formicidae: Myrmicinae). Chemoecology 2005, I 5:235-242.

32. Marlier JF, Quinet Y, de Bizeau JC: Defensive behaviour and biological activities of the abdominal secretion in the ant Crematogaster scutellaris (Hymenoptera: Myrmicinae). Behavioural Processes 2004, 67:427-440

33. Leclerq S, Braekman JC, Kaisin M, Daloze D: Venom constituents of three species of Crematogaster ants from Papua New Guinea. Journal of natural products 1997, 60: I I 43- I I 47.

34. Pasteels JM, Daloze D, Boeve JL: Aldehydic contact poisons and alarm pheromone of the ant Crematogaster scutellaris (Hymenoptera: Myrmicinae) - enzyme mediated production from acetate precursors. Journal of Chemical Ecology 1989, I5:1573-I56I.

35. Daloze D, de Biseau JC, Leclerq S, Braekman J-C, Quinet Y, Pasteels JM: $\quad$ (I3E, I 5E, I 8Z, 20Z)-I-Hydroxypentacosa-I 3, I I, I 8,20tetraen-I I-yn-4-one I acetate, from the venom of a Brazilian Crematogaster ant. Tetrahedron Letters 1998, 39:467|-4672.

36. Jones TH, Brunner SR, Edwards AA, Davidson DW, Snelling RR: 6Alkylsalicylic acids and 6-alkylresorcylic acids from ants in the genus Crematogaster from Brunei. Journal of Chemical Ecology 2005, $31: 407-417$

37. Laurent $P$, Hamdani A, Braekman JC, Daloze D, Isbell LA, de Biseau IC, Pasteels JM: New I-alk(en)yl-1,3,5-trihydroxycyclohexanes from the Dufour gland of the African ant Crematogaster nigriceps. Tetrahedron Letters 2003, 44: I383-1386.

38. Leclerq S, de Biseau JC, Braekman JC, Daloze D, Quinet Y, Luhmer $M$, Sundin A, Pasteels JM: Furanocembranoid diterpenes as defensive compounds in the dufour gland of the ant Crematogaster brevispinosa rochai. Tetrahedron 2000, 56:2037-2042.

39. Carlson DA, Mramba F, Sutton BD, Bernier UR, Geden CJ, Mori K: Sex pheromone of the tsetse species, Glossina austeni : isolation and identification of natural hydrocarbons, and bioassay of synthesized compounds. Medical and veterinary entomology 2005, 19:470-479.

40. Etges WJ, Jackson LL: Epicuticular hydrocarbon variation in Drosophila mojavensis cluster species. Journal of Chemical Ecology 200I, 27:2I25-2I49.

4I. Francke W, Plass E, Zimmermann N, Tietgen H, Tolasch T, Franke S, Subchev M, Toshova T, Pickett JA, Wadhams LI, Woodcock CM: Major sex pheromone component of female herald moth Scoliopteryx libatrix is the novel branched alkene (6Z, I3)methylheneicosene. Journal of Chemical Ecology 2000, 26:1135-1149.

42. Tentschert J, Bestmann HJ, Heinze J: Cuticular compounds of workers and queens in two Leptothorax ant species - a comparison of results obtained by solvent extraction, solid sampling, and SPME. Chemoecology 2002, I 2:|15-2|.

43. Lucas C, Fresneau D, Kolmer K, Heinze J, Delabie JHC, Pho DB: A multidisciplinary approach to discriminating different taxa in the species complex Pachycondyla villosa (Formicidae). Biological Journal of the Linnean Society 2002, 75:249-259.

44. Brown WV, Jaisson P, Taylor RW, Lacey MJ: Novel internally branched, internal alkenes as major components of the cuticular hydrocarbons of the primitive Australian ant Not- 
homyrmecia macrops Clark (Hymenoptera: Formicidae). Journal of Chemical Ecology 1990, 16:2623-2635.

45. Dalecky A, Renucci M, Tirard A, Debout G, Roux M, Kjellberg F, Provost E: Changes in composition of cuticular biochemicals of the facultatively polygynous ant Petalomyrmex phylax during range expansion in Cameroon with respect to social, spatial and genetic variation. Molecular Ecology 2007, I6:3778-379I.

46. Lucas C, Pho DB, Fresneau D, Jallon JM: Hydrocarbon circulation and colonial signature in Pachycondyla villosa. Journal of Insect Physiology 2004, 50:595-607.

47. Gibbs A, Pomonis JG: Physical properties of insect cuticular hydrocarbons: The effects of chain lengths, methyl branching and unsaturation. Comparative Biochemistry and Physiology 1995, I I 2 B:243-249.

48. D'Ettorre P, Heinze J, Schulz C, Francke W, Ayasse M: Does she smell like a queen? Chemoreception of a cuticular hydrocarbon signal in the ant Pachycondyla inversa. Journal of Experimental Biology 2004, 207: 1085-109I.

49. Lenoir A, Fresneau D, Errard C, Hefetz A: Individuality and colonial identity in ants: the emergence of a social representation concept. In Information Processing in Social Insects Edited by: Detrain C, Pasteels JM, Deneubourg JL. Basel: Birkhäuser; 1999:219-237.

50. Brandstaetter AS, Endler A, Kleineidam CJ: Nestmate recognition in ants is possible without tactile interaction. Naturwissenschaf ten 2008, 95:60I-608.

5I. Errard C, Regla JI, Hefetz A: Interspecific recognition in Chilean parabiotic ant species. Insectes Sociaux 2003, 50:268-273.

52. Emery C: Formiche raccolte da Elio Modigliani in Sumatra Engano e Mentawei. Annali del Museo Civico di Storia Naturale di Genova, Serie 2 1900, 20:66I-722

53. Carlson DA, Bernier UR, Sutton BD: Elution patterns from capillary GC for methyl-branched alkanes. Journal of Chemical Ecology 1998, 24:1845-1865.

54. Dunkelblum E, Tan SH, Silk PJ: Double-bond location in monounsaturated fatty acids by dimethyl disulfide derivatization and mass spectrometry: Application to analysis of fatty acids in pheromone glands of four Lepidoptera. Journal of Chemical Ecology 1985, I I:265-277.

55. $\mathrm{R}$ Development Core Team: $A$ language and environment for statistical computing 2007 [http://www.R-project.org.]. Vienna, R Foundation for Statistical Computing
Publish with Biomed Central and every scientist can read your work free of charge

"BioMed Central will be the most significant development for disseminating the results of biomedical research in our lifetime. "

Sir Paul Nurse, Cancer Research UK

Your research papers will be:

- available free of charge to the entire biomedical community

- peer reviewed and published immediately upon acceptance

- cited in PubMed and archived on PubMed Central

- yours - you keep the copyright
BioMedcentral 